\title{
Building Costumer Loyalty Through Marketing Mix Strategy With Satisfactory As Intervening Variable
}

\section{Fadli Adnin Nasution, Amrin Fauzi, and Nazaruddin Matondang}

Master of Management Department, Universitas Sumatera Utara

\section{Abstract}

Marketing mix should be formulated and combined as effectively as possible as it is the only marketing aspect that is controlled by the company, where the marketing mix strategy implemented by the company is responded by the costumers. The purpose of this study is to determine the most significant factors of the marketing mix that are influencing customer loyalty in Toko Amanah Central Pasar Medan Mall, to discover how marketing mix factors affect customer loyalty in Toko Amanah Central Pasar Medan Mall, to investigate how marketing mix factors affect loyalty through

Corresponding Author: Fadli Adnin Nasution fadliadninnasution@gmail.com

Received: 29 August 2018 Accepted: 18 September 2018 Published: 11 November 2018

Publishing services provided by Knowledge

(c) Fadli Adnin Nasution et al. This article is distributed under the terms of the Commons Attribution License, which permits unrestricted use and redistribution provided that the original author and source are credited.

Selection and Peer-review under the responsibility of the ICOI-2018 Conference Committee.

\section{G OPEN ACCESS}

customer satisfaction in Toko Amanah Central Pasar Medan Mall; to explore what policies are needed to be framed in relation to the factors of marketing mix in creating higher level of customer satisfaction in order to increase customer loyalty in Toko Amanah Central Pasar Medan Mall. The number of samples used in this study is 395 people. Data were collected using questionnaires and tested by using the Validity and Reliability Test; data were required to meet the elements of classical assumption test. Furthermore, test data analysis was done by using path analysis (Path Analysis), and coefficient of determination. This research concludes that price is the most significant variable in influencing consumer satisfaction, while the most significant variable in affecting consumer loyalty is the product.

Keywords: marketing mix, product, price, promotion, location, satisfaction, loyalty

\section{Introduction}

A company has to be effective and efficient in running its operational activities, because they are expected to have a competitive advantage compared to other contenders. There are many companies are seeking and utilizing every business opportunity in a tough competition of business environment.

Marketing mix determines the success or failure of a company in achieving their goals. As the only marketing aspect which is controlled by the company, marketing mix should be formulated and combined as effectively as possible, where the customer will respond to the marketing mix strategy. 


\section{Literature Review}

\subsection{Loyalty}

Loyalty is an essential factor in determining the success of a retail business as well as its market viability, because with the existence of loyalty then competitive advantage will bring success to the business. Griffin (2002) states that loyalty is described as non-random purchase manifested over time by some decision-making unit. Moreover, Kotler (2005) utters that loyalty is a repurchase done by a customer because of their commitment to a brand or company.

\subsection{Customer satisfactory}

According to Susanto (2000), customer satisfactory is a degree of one's feeling after weighing up the performance or the outcome that they feel compared to their expectations. Therefore, the level of satisfactory is a function of the difference between perceived performance and expectation.

\subsection{Marketing mix}

Swasta (2002) mentions that marketing mix is a combination of four variables or activities which is the core of the company's marketing system which consists of product, price, promotion, and distribution.

Based on the aforementioned explanation, the framework of this research can be seen as follows:

\section{Hypothesis}

In accordance with the aforementioned explanation, the hypothesis of this study can be defined as follows:

1. Product has effect on Satisfactory

2. Price has effect on Satisfactory

3. Promotion has effect on Satisfactory

4. Location has effect on Satisfactory 


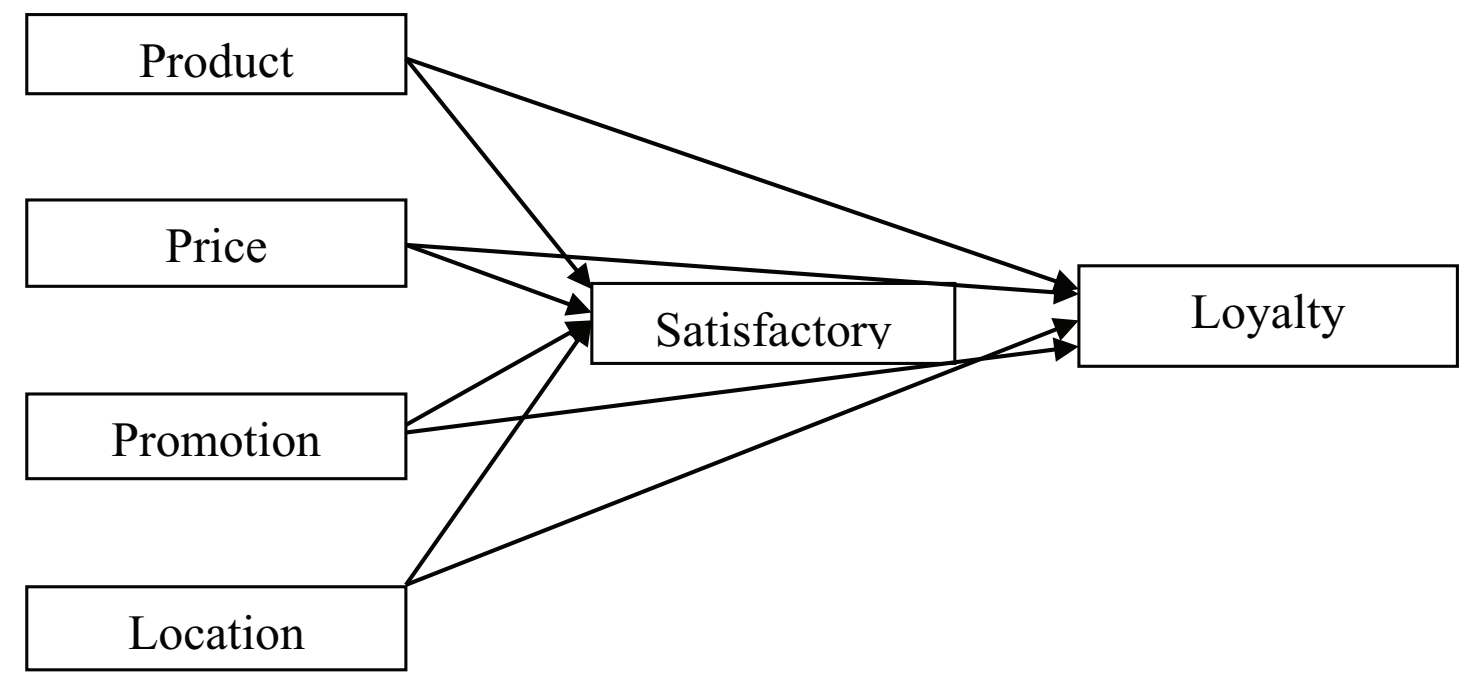

Figure 1: Research framework.

5. Product has effect on Loyalty

6. Price has effect on Loyalty

7. Promotion has effect on Loyalty

8. Location has effect on Loyalty

9. Product through Satisfactory has effect on Loyalty

10. Price through Satisfactory has effect on Loyalty

11. Promotion through Satisfactory has effect on Loyalty

12. Location through Satisfactory has effect on Loyalty

\section{Research Methodology}

\subsection{Research location}

This study is conducted in Central Pasar Medan Mall located at Jalan M.T. Haryono, Ps. Baru, Medan Kota. The duration of this study is from November 2015 to February 2016.

\subsection{Measured variables}

The indicator and measurement scale are used to facilitate this study. The analysis and discussion of variables used in this study are as follows:

1. Product $\left(X_{1}\right)$ 
2. Price $\left(X_{2}\right)$

3. Promotion $\left(X_{3}\right)$

4. Location $\left(X_{4}\right)$

5. Satisfactory $\left(Y_{1}\right)$

6. Loyalty $\left(Y_{2}\right)$

\subsection{Population and sample}

Population is a set of analysis units which contained information. The population of this study is all customers who have made purchase, at least, three times in Central Pasar Medan Mall, amounted to 365.976 people. The data are obtained through Central Pasar Medan Mall data, average per year, from 2014 to 2016.

\subsection{Data collection technique}

The data in this study consists of primary and secondary data. Data collection technique used to obtain the data is as follows:

1. Questionnaire

2. Documentation Study

\subsection{Data analysis technique}

\subsubsection{Coefficient of determination}

Coefficient of Determination is the square of correlation coefficient r multiplied by $100 \%$ to discover the amount of contribution the independent variable has in determining the dependent variable. The formula used to decide the degree of determination is as follows:

$$
K D=r^{2} \times 100 \%
$$




\subsubsection{Path analysis}

This analysis is used to determine the amount of effect of a variable to another variable, both direct influence and joint influence. The immensity of influence of an independent variable to a dependent variable is called path coefficient (Pyx). The relationship structure of these variables can be put into the regression equation, namely:

Sub-structure I: $Y_{1}=P Y_{1} X_{1}+P Y_{1} X_{2}+P Y_{1} X_{3}+P Y_{1} X_{4}+e$

Sub-structure II: $Y_{2}=P Y_{2} X_{1}+P Y_{2} X_{2}+P Y_{2} X_{3}+P Y_{2} X_{4}+P Y_{2} Y_{2}+e$

\section{Result and Discussion}

\subsection{Data quality test}

\subsubsection{Validity test}

Based on the data processing result, the validity test result is as follows:

Table 1 shows all indicators on each variable have fulfilled the validity requirements, which is $r_{\text {test }}>r_{\text {table }}$. Therefore, these indicators can be used to measure the variables of this study.

\subsection{Reliability test}

The criteria used to reveal the reliable indicator is by comparing Cronbach Alpha value with the Cronbach Alpha standard value of 0.600 , whereas if Cronbach Alpha value $>$ Cronbach Alpha Standard (0.600), the indicator is reliable. The result of reliability test can be seen in the following table:

\subsection{Hypothesis test}

\subsubsection{Sub-structure I}

Figure 2 shows the regression equation of Sub-structure I as follows:

$$
Y_{1}=0.140 X_{1}+0.221 X_{2}+0.100 X_{3}+0.135 X_{4}+0.899
$$


TABle 1: Product validity test.

\begin{tabular}{|c|c|c|c|}
\hline Questionnaire Item & $\mathbf{r}_{\text {test }}$ & $\mathbf{r}_{\text {table }}$ & Conclusion \\
\hline Product 1 & 0.365 & 0,113 & Valid \\
\hline Product 2 & 0.277 & & Valid \\
\hline Product 3 & 0.374 & & Valid \\
\hline Product 4 & 0.381 & & Valid \\
\hline Product 5 & 0.281 & & Valid \\
\hline Product 6 & 0.372 & & Valid \\
\hline Price 1 & 0.459 & & Valid \\
\hline Price 2 & 0.467 & & Valid \\
\hline Price 3 & 0.387 & & Valid \\
\hline Price 4 & 0.289 & & Valid \\
\hline Promotion 1 & 0.590 & & Valid \\
\hline Promotion 2 & 0.681 & & Valid \\
\hline Promotion 3 & 0.676 & & Valid \\
\hline Promotion 4 & 0.598 & & Valid \\
\hline Location 1 & 0.460 & & Valid \\
\hline Location 2 & 0.356 & & Valid \\
\hline Location 3 & 0.398 & & Valid \\
\hline Location 4 & 0.377 & & Valid \\
\hline Location 5 & 0.312 & & Valid \\
\hline Satisfactory 1 & 0.269 & & Valid \\
\hline Satisfactory 2 & 0.379 & & Valid \\
\hline Satisfactory 3 & 0.318 & & Valid \\
\hline Satisfactory 4 & 0.346 & & Valid \\
\hline Satisfactory 5 & 0.427 & & Valid \\
\hline Satisfactory 6 & 0.369 & & Valid \\
\hline Loyalty 1 & 0.296 & & Valid \\
\hline Loyalty 2 & 0.352 & & Valid \\
\hline Loyalty 3 & 0.363 & & Valid \\
\hline Loyalty 4 & 0.362 & & Valid \\
\hline Loyalty 5 & 0.441 & & Valid \\
\hline
\end{tabular}

\subsubsection{Sub-structure II}

Figure 3 exhibits the regression equation of Sub-structure II as follows:

$$
Y_{2}=0.166 X_{1}-0.004 X_{2}+0.054 X_{3}+0.121 X_{4}+0.125 Y_{1}+0.37 .
$$


TABLE 2: Reliability test result.

\begin{tabular}{l|c|c|c|}
\hline Variable & $\begin{array}{c}\text { Cronbach } \\
\text { Alfa Value }\end{array}$ & $\begin{array}{c}\text { Cronbach Alfa } \\
\text { Standard }\end{array}$ & Result \\
\hline Product & 0.608 & 0.600 & Reliable \\
\hline Price & 0.617 & & Reliable \\
\hline Promotion & 0.816 & Reliable \\
\hline Location & 0.627 & Reliable \\
\hline Customer Satisfactory & 0.618 & Reliable \\
\hline Loyalty & 0.606 & Reliable \\
\hline Source: Processed Primary & Data Primer, 2017. & \\
\hline
\end{tabular}

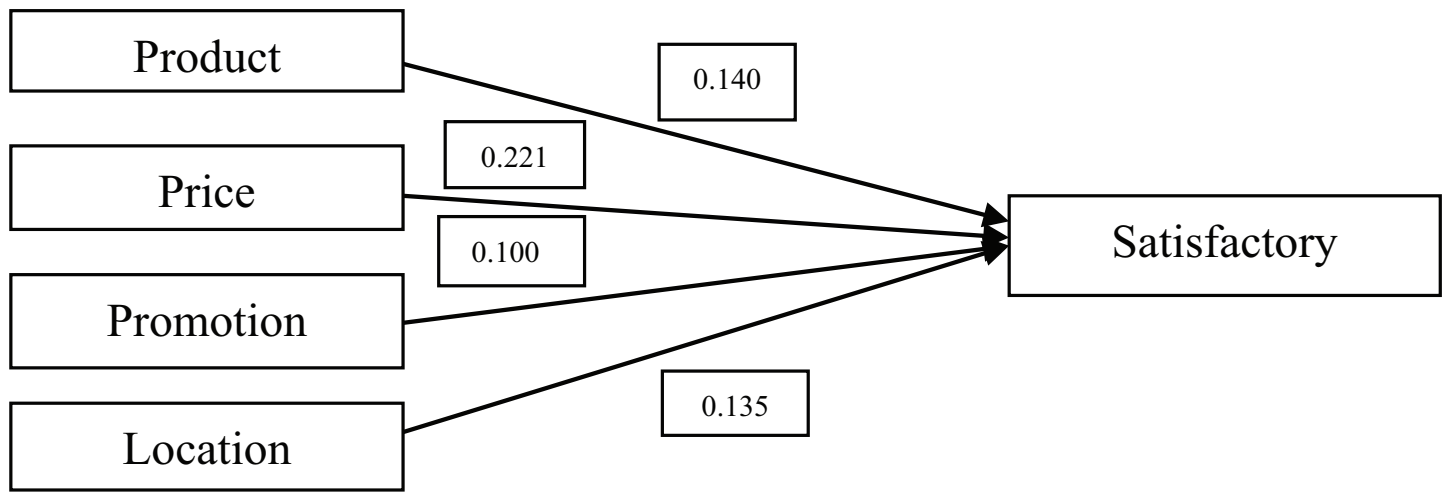

Figure 2: Result of path analysis of Sub-structure I.

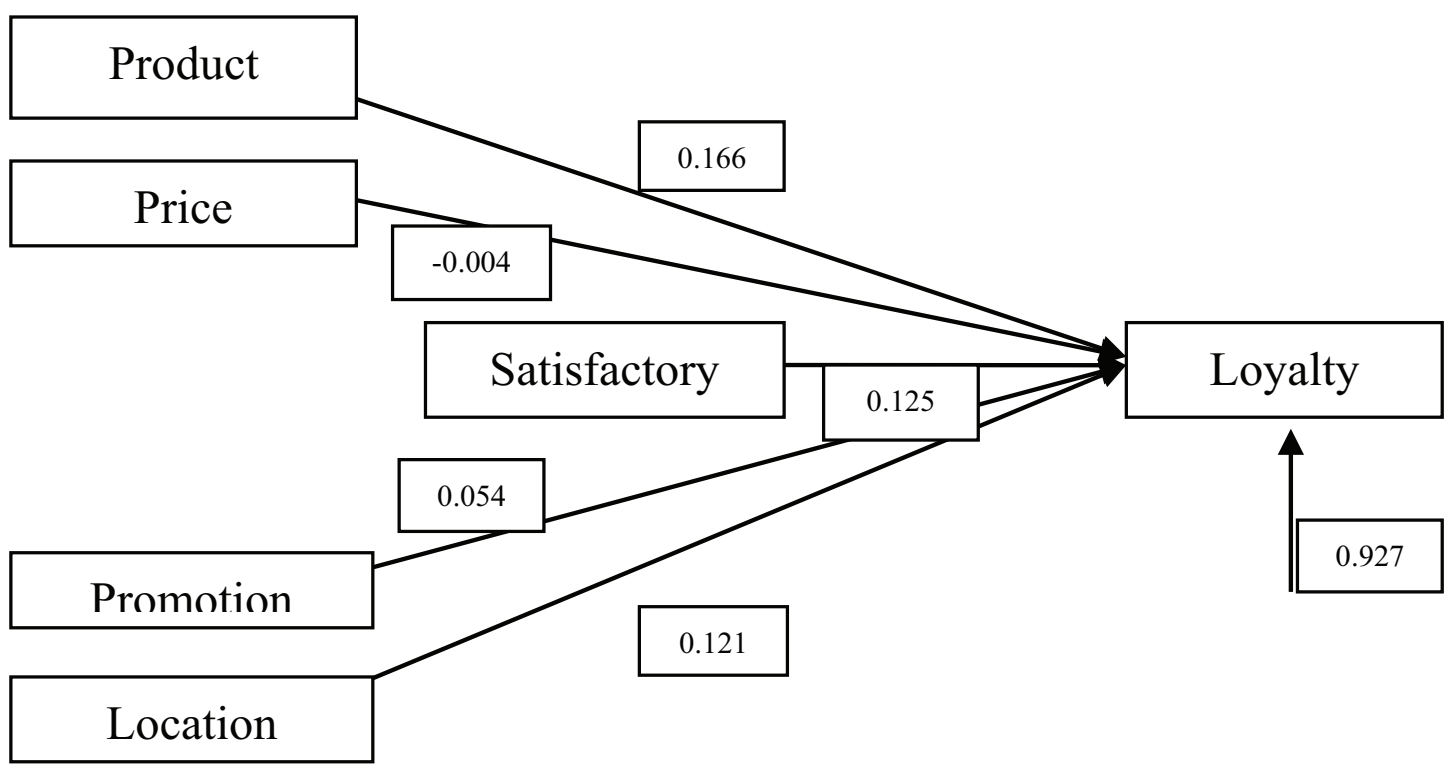

Figure 3: Result of path analysis of Sub-structure II.

\section{Hypothesis testing}

As known the hypothesis in this study is as follows:

$H_{0}$ 1: There is no significant effect of Product on Satisfactory in Toko Amanah Medan. 
$H_{a}$ 1: There is a significant effect of Product on Satisfactory in Toko Amanah Medan.

$\mathrm{H}_{0}$ 2: There is no significant effect of Price on Satisfactory in Toko Amanah Medan.

$\mathrm{H}_{a}$ 2: There is a significant effect of Price on Satisfactory in Toko Amanah Medan.

$\mathrm{H}_{0}$ 3: There is no significant effect of Promotion on Satisfactory in Toko Amanah Medan.

$\mathrm{H}_{a}$ 3: There is a significant effect of Promotion on Satisfactory in Toko Amanah Medan.

$\mathrm{H}_{0}$ 4: There is no significant effect of Location on Satisfactory in Toko Amanah Medan.

$\mathrm{H}_{a}$ 4: There is a significant effect of Location on Satisfactory in Toko Amanah Medan.

$\mathrm{H}_{0}$ 5: There is no significant effect of Product on Loyalty in Toko Amanah Medan.

$\mathrm{H}_{a}$ 5: There is a significant effect of Product on Loyalty in Toko Amanah Medan.

$\mathrm{H}_{0}$ 6: There is no significant effect of Price on Loyalty in Toko Amanah Medan.

$\mathrm{H}_{a}$ 6: There is a significant effect of Price on Loyalty in Toko Amanah Medan.

$\mathrm{H}_{0}$ 7: There is no significant effect of Promotion on Loyalty in Toko Amanah Medan.

$\mathrm{H}_{a}$ 7: There is a significant effect of Promotion on Loyalty in Toko Amanah Medan.

$\mathrm{H}_{0}$ 8: There is no significant effect of Location on Loyalty in Toko Amanah Medan.

$\mathrm{H}_{a}$ 8: There is a significant effect of Location on Loyalty in Toko Amanah Medan.

$\mathrm{H}_{0}$ 9: There is no significant effect of Satisfactory on Loyalty in Toko Amanah Medan.

$\mathrm{H}_{a}$ 9: There is a significant effect of Satisfactory on Loyalty in Toko Amanah Medan.

\section{Conclusion and Suggestion}

\subsection{Conclusion}

Price is the most significant variable in affecting Satisfactory. Meanwhile, the most significant variable to affect Loyalty is Product.

Based from the result, there are factors of marketing mix which are affecting Loyalty, such as:

1. Product significantly affects Loyalty. The contribution value of Product in affecting Loyalty is 0.166 . 
2. Price has no significant effect on Loyalty. The contribution value of Price in affecting Loyalty is -0.004 .

3. Promotion has no significant effect on Loyalty. The contribution value of Promotion in affecting Loyalty is 0.054 .

4. Location has no significant effect on Loyalty. The contribution value of Location in affecting Loyalty is 0.121 .

From the result it can be known there are factors of marketing mix which re affecting Satisfactory at Central Pasar Medan Mall, as follows:

1. The effect of Product on Loyalty through Satisfactory is 0.018 . This magnitude of influence is not as dominant as other factors.

2. The effect of Price on Loyalty through Satisfactory is 0.028 . This is the highest magnitude of influence compared to other factors. Hence, it is very essential to highly concern the price offered by UD Amanah.

3. The effect of Promotion on Loyalty through Satisfactory is 0.013 . This magnitude of influence is not as dominant as other factors.

4. The effect of Location on Loyalty through Satisfactory is 0.017 . This magnitude of influence is not as dominant as other factors.

Policies needed to be taken in regard of the factors of marketing mix to create high level of Satisfactory in order to increase Loyalty at Central Pasar Medan Mall:

1. An important thing that can be done is to communicate with the suppliers in regard of the quality of the product, by providing high quality material.

2. Comparing the price set by company with competitor's price. In addition, the management of Central Pasar Medan Mall can also utilize the price market mechanism.

3. Provide a discount for specific products with low rate of sales.

4. The management of Central Pasar Medan Mall should accommodate decent facility to increase Satisfactory.

\subsection{Suggestion}

1. To be able to increase loyalty, every company's management should be attentive to improve the quality of the product. 
2. Price is a very sensitive variable, for that reason, a company should compare the price of its product with other companies so the company can set a lower price.

3. Promotion can be a good method to increase the company's sales, because the level of customer decision to purchase will be increased as well. Since customers are already familiar with the promotion organized by the company, consequently, the level of loyalty will increase.

4. Location can improve the prestige to the customers, then the company's management should pay attention to the location to be used in marketing the product.

\section{References}

[1] Aryotedjo. (2005). Pengaruh Kualitas Jasa, Kepuasan dan Komitmen Pelanggan Terhadap Loyalitas Konsumen Pada Bisnis Retail. Jurnal Bisnis dan Manajemen, vol. 5, no. 2, pp. 223-232.

[2] Basu. (1999). Asas-Asas Pemasaran, Edisi Ketiga. Yogyakarta: Penerbit Liberty.

[3] Bungin, B. (2005). Metodologi Penelition Kuantitatif (Edisi Pertama, Cetakan Pertama). Jakarta: Penerbit PT. Rajagrafindo Persada.

[4] Dasril. (2009). Analisis Pengaruh Strategi Bauran Pemasaran Terhadap Perilaku Pembelian Konsumen Tekstil di Kota Medan. Thesis, Magister Ilmu Manajemen Sekolah Pascasarjana USU, Medan (tidak dipublikasikan).

[5] Faizul. (2008). Pengaruh Strategi Bauran Pemasaran Ritel Terhadap Kepuasan dan Hubungan Dengan Loyalitas Pelanggan Plaza Medan Fair di Medan. Thesis, Magister Ilmu Manajemen Sekolah Pascasarjana USU, Medan (tidak dipublikasikan). 